\title{
Remarks on the Real-Utopia Project: the contribution of an emancipatory social science
}

\author{
Apontamentos sobre o Projeto Real Utopia: o contributo de uma ciência \\ social emancipatória
}

\section{Notas sobre el Proyecto Real Utopia: la contribución de una ciencia social emancipatoria}

\author{
Notes sur le Projet de Réel Utopia: la contribution d'une science sociale \\ emancipatrice
}

\author{
Marcela Fernanda da Paz de Souza ${ }^{1}$ \\ Received 02/12/2016; Revised and approved in 17/04/2017; Accept in 30/04/2017 \\ DOI: http://dx.doi.org/10.20435/inter.v18i3.1448
}

\begin{abstract}
Interview: Erik Olin Wright
Professor of Sociology at the University of Wisconsin (Madison) and former President of the American Association of Sociology, 2011-2012

By: Marcela Fernanda da Paz de Souza

Post-doctorate in Urban and Regional Studies (PNPD / UFRN) and PhD in Social Sciences (UFJF).Research Inequalities, Sociology of Work and Methodology.
\end{abstract}

\section{INTRODUCTION}

Erik Olin Wright is one of the great neo-Marxist exponents. With a work devoted to the "reconstruction of the Marxist tradition of social theory" (WRIGHT, 2005, p. 325), in a relevant contribution to class analysis, such as the class structure-mapping project that captured the contradictory class locations - 'middle class' - in contemporary capitalist society (SANTOS, 1998, 2002).

From our suggestion of dialogue, Wright will present us with basic questions for the reader's approach to the Real Utopia Project, within the scope of an Emancipatory Social Science. As he himself points out, the construction of the Project and its guiding axes is on a continuous path.

By proposing an emancipatory social science, Wright (2010) offers the mapping and analysis of new institutional designs, which capture, present and / or outline viable alternatives to the various forms of human oppression in the capitalist world. It is through the construction and systematization of scientific knowledge that emancipatory paths are delineated and relevant knowledge on the nuts and bolts of the social reality are generated.

Through systematized knowledge, the existing alternatives are mapped and / or the possibility of their creation is verified, corresponding to three basic criteria: 'desirable', viability and feasibility.

The foundational proposition guiding emancipatory social science is that the transformations of existing social and institutional structures have a potential to greatly reduce human suffering, and to widen the possibilities for its flowering. The 'social' aspect of science necessarily

\footnotetext{
${ }^{1}$ Universidade Federal do Rio Grande do Norte (UFRN), Natal, Rio Grande do Norte, Brasil
} 
requires the transformation of the social world in order to human emancipation to occur. This emancipation is not possible only by the transformation within the people. On the other hand, the empirical element has at its core the moral character and includes in its proposal the elimination of oppression, as well as the creation of conditions for human flourishing (WRIGHT, 2010).

It is important to emphasize that the proposal of a 'Real Utopia' emerges in the midst of a tension between the dream and the practice of an emancipatory human achievement, whose pragmatics is made possible by human imagination and human vision (WRIGHT, 2010). In the next pages, this enterprise of a real utopia will become more concrete to our gaze.

\section{DEEPENING THE SUBJECT}

\section{1) In general could you talk a little about the connection of your studies to the Methodological Individualism?}

I am a methodological pluralist. What does this mean? It means that I seek to understand mechanisms (causal processes) that exist in the world and generate the social phenomena that we observe. Some of these mechanisms are closely tied to the properties of individuals; others are embedded in the relations among individuals; and still others a located in more macro-institutions. I believe that macro-phenomena are always connected to micro-processes - they have what can be called micro-foundations - but this does not mean that macro-phenomena can be reduced to micro-individual level processes.

\section{2) How the principles of equality, democracy, community / solidarity and sustainability can be observed in the three basic tasks of emancipatory social science?}

Emancipatory social science requires normative foundations. Indeed, this is what anchors the claim that the social sciences can contribute to human emancipation: The goal is to identify the ways in which existing social structures and institutions obstruct the realization of the kinds of the values needed for human flourishing.

I see emancipatory social science therefore as having four tasks (not just the three I identified in Envisioning Real Utopias): 1. Normative foundations. 2. The diagnosis and critique of existing social structures and institutions in terms of those foundations. 3. Alternatives that would better realize emancipatory values. 4 . A theory of transformation. The normative foundations matter because they determine the critical questions that direct the scientific investigations within the other three tasks.

\section{3) Is Democratization at the center of capitalism's transcendence?}

Capitalism is a fundamentally undemocratic structure of power over the economy in two fundamental ways.

First, perhaps the most fundamental right that accompanies private ownership of capital is the right to decide where and when to invest and disinvest strictly on the basis of the private self-interests of owners. The decision by a corporation to move production from one place to another is a private decision, even if closing a factory in the United States and moving it to a country with cheap labor and lax environmental regulations devastates the lives of people who previously worked in the factory and destroys the value of housing in the surrounding community. 
The people in the devastated community have no rights to participate in the decision in spite of the fact that it affects their lives deeply. This profoundly violates the democratic principle that people should be able to participate in decisions that significantly affect their lives. Second, capitalist firms are allowed to be organized as workplace dictatorships. An essential power of private ownership of businesses is that the owners have the right to tell employees what to do. That is the basis of the employment contract: the job seeker agrees to follow the orders of the employer in exchange for a wage. This also violates democratic values. To fully realize the value of democracy in an economy requires the democratization of both the broad contours of investment and disinvestment and the workplace. This would require the transcendence of capitalism.

\section{4) Could you explain, in general terms of reflection, in which aspects Adam Przeworski contributions influenced your reflection on the Ruptural Transformation?}

The heart of Przeworski's analysis of the problem of moving from capitalism to socialism is the idea of a dilemma: Socialist parties have a series of nested, unavoidable dilemmas as they attempt to mobilize workers and others for the political project of transcending cpaitalism. The key dilemma for the problem of rupture is the dilemma of trying to break with capitalism through democratic means - by winning elections and instituting an anticapitalist political project. Those policies will be enormously disruptive and inevitably will create a transition trough for an extended period - i.e. a deterioration in economic conditions because of the flight of capital and other processes. This will make it very difficult for Ruptural socialists to win a second election, especially since the coalition of class forces that back them is likely to disintegrate. Therefore the temptation will be to resort to anti-democratic means - cancel elections, repress the opposition, etc. But if they abandon democratic norms and impose the necessary repressive means to stay in power, then the result of the transition will not be a deeply democratic, egalitarian society.

\section{5) You presents the case of Porto Alegre as a good example of Interstitial Transformation. Why?}

PB actually combines what I call symbiotic reforms with an interstitial strategy. A symbiotic reform is a reform from above that changes the rules of the game in ways that helps to solve problems within the system while simultaneously opening up greater spaces for initiatives from below to build alternatives. PB embodies the values of democracy, equality and solidarity and therefore has the potential to be what I call a "real utopia." Once in place, it unleashed all sorts of new energy and initiatives from communities. But of course, this process was always vulnerable to processes which would undermine its viability and creativity. To sustain its real utopian character required fairly demanding political conditions. And it seems, over time, that these conditions have greatly weakened.

\section{6) In what forms the interstitial strategy can be promoted by NGOs, social movements, trade unions, informal supporters and social networking managers?}

Interstitial strategies attempt to build elements of the alternative world we want to see in the world as it is. This requires direct involvement of ordinary people creating new ways of doing things rather than elites imposing new institutions from above. Social movements and other collectivities with deep ties to communities are positioned to facilitate this by providing 
resoucres, advice, knowledge, coordination, and the like. But, of course, these movements can also be manipulative and domineering, and there is always the risk that they engage in fostering community initiatives for purposes of enhancing their own power rather than promoting social transformation from below.

\section{7) Although, at first, interstitial strategies are operationalized with out the state, this fact does not prevent it from use to answer specific demands of communities through a symbiotic transformation. Could you present some examples?}

I now use a slightly different language for talking about the interplay of symbiotic and interstitial strategies. I refer to these strategies as the strategy of taming capitalism and the strategy of eroding capitalism. Taming capitalism is the social democratic strategies of creating state-based institutions to counteract some of the harms of capitalism; eroding capitalism is the more anarchist strategy of building anticapitalist ways of life and economic activity in the spaces where this can be done. The combination involves reforms from above that also expand those spaces. Unconditional basic income is a good example: it neutralize directly some harms of capitalism (eg reduces poverty) while making it easier for people to build noncapitalist circuits of economic activity.

\subsection{Deepening the subject - Real Utopia Project}

8) One of yours main projects, nowaday, is the Real Utopia Project. What were there rasons that have led you towards it?

The Real Utopias project as a specific project began around 1992, but the concern with the problem of alternatives and how to integrate this into the critique of capitalism and other structures of oppression has be part of my work since I was a student. In 1971 I organized a semester-long course among graduate students called "Utopia and Revolution" where we discussed many of these same issues. And at various times in the 1970s and 1980-s I published essays exploring the problem of emancipation, alternatives, socialism, and related matters. So the theme was not new, but the project was. The main context for the project was the collapse of the statist economies organized under the banner of "Communism", and the arrogant triumphalism of neoliberal capitalism proclaiming "There is No Alternative." Like many people on the Left, I felt that the left continued to have many creative and powerful ideas about alternatives, but that these ideas no longer held together within an overarching framework that gave them coherence. The Real Utopias project is an attempt to make a contribution around these issues.

\section{9) What is the objective of the Real Utopia Project?}

The most basic objective of the real utopia project is to clarify two things: first, what designs for new institutions can effectively embody emancipatory ideals; second, what strategies can people adopt in the present to move us in the direction of these alternatives? The first question asks for clarification of the destinations for emancipatory struggles over institution-transforming and institution-building. The second question asks for clarification of the strategies that can advance these struggles. All of this is very complex. It requires a serious exploration of the normative foundations of human emancipation - what values are we deeply committed to - and 
of the institutional and structural requirements for the realization of those values. This means avoiding naïve endorsement of all militant actions that fly the banner of radical transformation, but equally avoiding cynicism which sees the flaws in every effort at human emancipation.

\section{0) Can you explain the connection between the Marxist tradition with Real Utopia Project?}

The Marxist tradition remains the tradition of intellectual debate and discussion within which the idea of a radical transformation of social structures and institutions in the service of human emancipation remains most central. This tradition has three main poles of theoretical work: First, it involves a critique of capitalism as a system of economic relations, especially class relations, that generates harms in the world and ultimately blocks the realization of human potentials. Second, it involves a theory - or at least a conceptualization - of an alternative to capitalism, building around egalitarian and democratic principles. A third, involves a theory of the overall dynamics, contradictions, and trajectory of capitalism that make this alternative achievable. Of these three components, I feel the first is the most well-developed, with the strongest scientific foundations. I refer to this as the class analysis of capitalism. The second component remains the crucial source of motivation and inspiration with Marxism, suggesting that another world is possible, but it is often theoretically underdeveloped. And the third component is, in many respects, quite flawed. While Marxists have elaborated many trends and contradictions within capitalism, the theory of the trajectory of capitalism into the future - especially the core idea that the contradictions of capitalism intensify in ways that makes the transcendence of capitalism easier over time - is not satisfactory. My work on real utopias draws heavily from class analysis as the basis for the diagnosis and critique of capitalism. It also tries to make a systematic contribution to the second pole of the Marxist tradition, by elaborating a way of understanding socialism that places emphasis on the "social" in socialism, and anchors socialism in pluralistic vision for a heterogeneous array of institutions needed to fully embody democratic-egalitarian principles. Finally, and I think in a more limited way, I try to advance the understanding of trajectories and strategies into the future by exploring the interplay of what I call interstitial strategies of transformation and symbiotic strategies.

\section{1) You developed a typology and a dimensional space (Frame 1 and 2) with the institutional designs of worker-owned cooperatives: existing ones and planned in a Real Utopia Project context.}

\begin{tabular}{clcc|}
\multicolumn{1}{c}{} & \multicolumn{2}{c}{ Governance } \\
\cline { 3 - 3 } Owershop & Capitalist & $\begin{array}{c}\text { Conventional } \\
\text { Capitalist firms }\end{array}$ & Co-determination \\
\cline { 3 - 4 } & Worker & ESOPS & FULL cooperatives \\
\cline { 3 - 4 } & &
\end{tabular}

Frame 1 - Typology of cooperatives and hybrid forms (WRIGHT, 2015a, p. 6).

This typology could also be treated as a dimensional space rather than dichotomies, where each dimension was continuous and thus also sorts of intermediate and more complexly mixed forms would be possible. Here is a rough sketch. (WRIGHT, 2015a, p. 6). 
Degree of Democratic Governance

\begin{tabular}{|c|c|c|c|c|c|}
\hline & & Authoritarian & & & Democratic \\
\hline & $\begin{array}{l}\text { Zero: full } \\
\text { Capitalist } \\
\text { ownershi }\end{array}$ & $\begin{array}{l}\text { Conventional } \\
\text { capitalist firm }\end{array}$ & $\begin{array}{l}\text { Capitalist firm } \\
\text { with works } \\
\text { councils }\end{array}$ & $\begin{array}{c}\text { Strong } \\
\text { co-determination }\end{array}$ & \\
\hline $\begin{array}{l}\text { Degree } \\
\text { of worker } \\
\text { ownership }\end{array}$ & & Parcial ESOP & $\begin{array}{c}\text { Mixed } \\
\text { Cooperative }\end{array}$ & & \\
\hline & $\begin{array}{l}\text { High: full } \\
\text { Worker } \\
\text { ownership }\end{array}$ & $\begin{array}{l}\text { Full } \\
\text { ESOP }\end{array}$ & $\begin{array}{c}\text { ESOP with } \\
\text { works councils }\end{array}$ & & $\begin{array}{l}\text { Full worker } \\
\text { cooperative }\end{array}$ \\
\hline
\end{tabular}

Frame 2 - Degree of Democratic Governance (WRIGHT, 2015a, p. 6).

\section{With the seminars of the new Pathways Project to the Cooperative Market Economy, a change of this typology is possible?}

The Pathways to a Cooperative Market Economy is an on-going project in which I am organizing research workshops in four or five countries over a two year period in which we discuss different distinctive pathways through which worker cooperatives an incubated, develop, and sustained. So far we have had two such workshops - one in Spain exploring the Mondragon model and a recent one in Argentina exploring the enterprise takeovers by workers since 2001. Additional workshops are planned in Soth Africa and then in Europe. Our hope is that after each workshop we will rethink the overall typology of pathways so that over time it will have greater analytical power. At the moment we have framed the problem in terms of the democratization of governance within an enterprise and the degree or form of worker ownership. But clearly this is very preliminary.

\section{2) What are the main challenges to undertake a project of Democratizing Finance? It seems more complex to carry it out, compare, for example, to the Pathways to the Cooperative Market Economy new Project.}

The democratizing finance project is indeed challenging. One problem is the technical difficulty of understanding finance. It is rare toi find someone with full mastery over the technical issues who is also a committed anti-capitalist, but without that technical knowledge all sorts of pretty silly things can be said and proposed. A second problem is that while it is very easy to specify a series of rules and policies that can be imposed from above that would contribute to "taming" the most destructive aspects of capitalist finance - these include the familiar regulatory devices of the past plus some new proposed regulatory procedures - it is much more difficult to connect these to the strategic problem of transcending capitalism. One can do this in a vague sort of way by invoking things like democratic accountability and egalitarian access, but it is much harder to give institutional design precision to the argument. It is plausible that worker-owned cooperatives will be one component of a desirable post-capitalist future, and thus building them now is in part building the future inside of the present. It is much less clear what are the elements of a post-capitalist system of finance that can be built in the present, both because it is harder 
top specify the post-capitalist system of finance and because it is hard to figure out pieces of this that can be imported into the present.

\section{REFERENCES}

SANTOS, José Alcides Figueiredo. A teoria e a tipologia de classe neomarxista de Erik Olin Wrigh. Dados, Rio de Janeiro, v. 41, n. 2, p. 377-410, 1998. Available in: <http://www.scielo.br/scielo.php?script=sci arttext\&pid=S0011-52581998000200004\&Ing=en\&nrm=iso>. Access in: 25 jun. 2015. DOI: http://dx.doi. org/10.1590/S0011-52581998000200004.

2002.. Estrutura de posições de classe no Brasil. Belo Horizonte: Editora UFMG; Rio de Janeiro: IUPERJ,

WRIGHT, Erik Olin. Falling into Marxism: Choosing to Stay. In: SICA, A.; TURNER, S. (Org.). The disobedient generation: social theorists in the sixties. Chicago: University of Chicago Press, 2005. p. 325-349.

. Envisioning Real Utopias. London: Verso, 2010. Available in: <https://www.ssc.wisc.edu/ wright/ ERU.htm>. Access in: 20 july 2014.

. Meandering Reflections from the pathways to a cooperative market economy workshop. 2015a. Available in: <https://www.ssc.wisc.edu/ wright/Cooperative-pathways/Reflections\%20on\%20the\%20 pathways\%20to\%20a\%20cooperative\%20market\%20economy\%20workshop\%20--\%20April\%2010.pdf>. Access in: 15 sep. 2015.

Some reflections on the democratizing finance project. 2015b. Available in: <https://www. ssc.wisc.edu/ wright/Democratizing-Finance/Some\%20reflections\%20by\%20EOW\%20on\%20the\%20 democratizing\%20finance\%20project\%20following\%20the\%20May\%201\%20workshop.pdf>. Access in: 15 sep. 2015.

\section{About the authora:}

Marcela Fernanda da Paz de Souza: Urban and Regional Studies Postdoctoral degree by Federal University of Rio Grande do Norte (UFRN), PNPD scholarship student - State and Public Policies research line. Doctorate course in Social Sciences by the Social Sciences Graduate Program Public Policies and Social Inequality research line in Federal University of Juiz de Fora (PPGCSO/UFJF).

E-mail: marceladapaz2015@gmail.com 
